\title{
PEMBERIAN PUPUK UREA DAN PUPUK KANDANG KAMBING PADA TANAH ULTISOL BILAH HULU PADA PERTUMBUHAN PRODUKSI TANAMAN PAKCOY (Brassica rapa L)
}

(Application of Urea and Goat Manure on Ultisol Soil Bilah Hulu On Pakcoy Plant Production Growth)

\author{
Fitra Syawal Harahap ${ }^{1}$, Mulya Rafika ${ }^{2}$, Zuriani Ritonga ${ }^{3}$, Rendi Fitra Yana ${ }^{4}$ \\ ${ }^{1}$ Program Studi Agroteknologi, Fakultas Sains dan Teknologi, \\ Universitas Labuhanbatu Sumatera Utara. \\ ${ }^{2}$ Program Studi Akuntansi, Fakultas Ekonomi dan Bisnis, \\ Universitas Labuhanbatu Sumatera Utara. \\ ${ }^{3}$ Program Studi Manajemen, Fakultas Ekonomi dan Bisnis, \\ Universitas Labuhanbatu Sumatera Utara. \\ ${ }^{4}$ Program Studi Komunikasi Penyiaran Islam, Fakultas Agama Islam, \\ Universitas Al Washliyah, Labuhanbatu Sumatera Utara \\ Penulis Koresponden: fitrasyawalharahap@gmail.com
}

Article Submitted: 26-02-2021

Article Accepted: 23-05-2021

\begin{abstract}
Application of Urea Fertilizer and Goat manure in a Ultisol for green mustard plants (Brassica rapa $\mathrm{L}$ ) aimed to determine the fertilizer treatment of goats sometimes goats to increase leaf area, root volume, and fresh weight of plants. And Interaction of fertilizer application, sometimes goat fertilizer (ts/ha) and urea fertilizer on green mustard plants. This research was conducted in Sona Village with a height of 18 meters above sea level in Labuhanbatu Regency from December 2019 until March 2020. The material used was green mustard seeds, goat manure. Urea fertilizer, water Tools used are cutter blades, analytical scales, rulers, scissors, mortars, measuring flasks, buckets, calipers, neat ropes, hoes. The research will be conducted with a factorial group design. The first factor is the provision of factorial Group Design consisting of 2 factors, the first factor is Goat Cage fertilizer (K) consisting of 3 levels and the second factor is the provision of Urea fertilizer consisting of 2 dose levels, so we get 6 treatment combinations every 4 replications so that 24 plots were obtained. Each plot consisted of 25 plants and taken 5 plants as samples. The parameters observed were plant height $(\mathrm{cm})$, number of leaves (strands), leaf area $\left(\mathrm{cm}^{2}\right)$, root volume $(\mathrm{ml})$, and weight of fresh plant weight (g). Data obtained from the results of the study were statistically analyzed with variance and continued with Duncan's New Multiple Range Test (DNMRT) at 5\% level. Results of research The treatment of fertilizer sometimes goat (ts/ ha) with a dose of $2 \mathrm{ts} / \mathrm{ha}$ and urea fertilizer at 100 $\mathrm{kg} / \mathrm{ha}$ can increase leaf area, root volume, and plant fresh weight. As well as the interaction of fertilizer application, sometimes goat fertilizer $(\mathrm{t} / \mathrm{ha})$ and urea fertilizer have a significant influence on the parameters of leaf area, root volume, and plant fresh weight.
\end{abstract}

Keywords: Goat Manure, Green Mustard Plant, Urea Fertilizer

\section{PENDAHULUAN}

Pakcoy (Brassica rapa L.) sayuran merupakan tanaman hortikultura yan memiliki peran sebagai sumber vitamin dan mineral. Permintaan masyarakat terhadap Pakcoy semakin meningkat. Konsumsi Pakcoy mengalami kenaikan dari 1.304 kg/kapita/tahun pada 2013 menjadi 1.408 
kg/kapita/tahun pada 2016 (Statistik, B.P., 2016). Produksi Pakcoy di Indonesia meningkat antara $3-7 \%$ per tahun dalam kurun waktu lima tahun dari 2010-2014 dan kemungkinan akan terus mengalami peningkatan setiap tahun.

Pakcoy layak dikembangkan untuk memenuhi permintaan konsumen. Kondisi wilayah Indonesia cocok untuk budidaya tanaman ini. Menurut Haryanto et al., (2006) dari aspek agroklimat, beberapa wilayah di Indonesia sangat potensial untuk budidaya sayuran, seperti Sumatera, Jawa, sebagian Kalimantan, dan Sulawesi. Masa panen yang relatif singkat dan mudahnya dalam pemeliharaan juga merupakan daya tarik untuk mengusahakan Pakcoy. Peningkatan produksi dapat ditempuh melalui usaha intensifikasi dan ekstensifikasi lahan (Moenandir, 2004).

Budidaya tanaman secara organik tidak hanya sebatas meniadakan penggunaan bahan sintetis, tetapi juga menuntutagar lahan yang digunakan tidak tercemar serta mempunyai aksesibilitas yang baik dan berkesinambungan. Pemberian pupuk organik ke dalam tanah dapat mempengaruhi dan memperbaiki sifat-sifat tanah baik fisika, kimia maupun biologi tanah (Pranata, 2010).

Dalam upaya meningkatkan produksi dan pendapatan petani yaitu dengan menggunakan pemupukan yang seimbang dan varietas unggul. Upaya meningkatkan produktivitas tanaman kedelai, maka perlu usaha pemakaian pupuk sebagai sumber hara. Salah satu ketersediaan unsur hara dalam tanah dan pada tanaman dapat dilakukan dengan cara peemberian bahan organik (Moenandir, 2004). Pemupukan merupakan faktor penting dalam budidaya tanaman yang menunjang keberhasilan produksi Pakcoy. Menurut Wijaya K.,(2010) tanaman membutuhkan unsur hara yang selalu tersedia selama siklus hidupnya untuk dapat tumbuh dan berproduksi dengan baik. Degradasi lahan yang disebabkan oleh penggunaan pupuk kimia yang berlebihan mempengaruhi kualitas produk sayuran yang dihasilkan. Budidaya tanaman yang ramah lingkungan perlu digiatkan untuk mengatasi masalah penurunan kualitas lahan. Untuk memperbaiki kualitas tanah, dapat ditempuh dengan beberapa cara seperti mengurangi penggunaan pupuk kimia dan menggunakan pupuk organik seperti pupuk hijau, pupuk kompos ataupun pupuk kandang. Beberapa diantara kotoran hewan yang dapat dimanfaatkan sebagai pupuk organik yaitu kotoran sapi, kotoran kambing dan kotoran kambing (Hartatik dan Setyorini, 2011).

Penggunaan bahan organik dapat menjadi alternatif solusi untuk mengurangi ketergantungan terhadap penggunaan pupuk kimia dalam meningkatkan produktivitas tanaman Pakcoy. Penambahan bahan organik dalam tanah akan dapat memperbaiki struktur tanah dan meningkatkan stabilitas agregat tanah yang nantinya dapat memelihara aerasi tanah dengan baik dan dapat menunjang peningkatan efisiensi penggunaan pupuk (Hayati et al., 2012).

Pupuk organik merupakan pupuk yang berasal dari tumbuhan mati, kotoran hewan dan/atau bagian hewan dan/atau limbah organik lainnya yang telah melalui proses rekayasa, berbentuk padat atau cair, dapat diperkaya dengan bahan mineral dan/atau mikroba yang bermanfaat untuk meningkatkan kandungan hara dan bahan organik tanah serta memperbaiki sifat fisik, kimia dan biologi tanah (Permentan No.70/Permentan/SR.140/10/2011). Salah satu jenis pupuk organik adalah pupuk kandang. Menurut Syekhfani (2000) pupuk kandang memiliki sifat yang tidak merusak tanah, menyediakan unsur hara makro dan mikro. Selain itu pupuk kandang berfungsi untuk meningkatkan daya menahan air, aktivitas mikrobiologi tanah, nilai kapasitas tukar kation dan memperbaiki struktur tanah.

Salah satu jenis pupuk kandang yaitu pupuk kandang dari kotoran kambing. Menurut Tan (1993), pupuk kotoran 
kambing memiliki keunggulan dibandingkan dengan pupuk kotoran sapi dan kuda, yaitu memiliki unsur makro Nitrogen $(\mathrm{N})$, Fosfor $(\mathrm{P})$, serta Kalium (K) lebih tinggi. Berdasarkan penelitian Indrasari dan Syukur (2006), pemberian bahan organik seperti pupuk kandang kotoran kambing sampai dengan $30 \mathrm{t} / \mathrm{ha}$ dapat meningkatkan kandungan bahan organik, $\mathrm{Zn}$ jaringan tanaman, berat segar maupun berat kering akar tanaman jagung. Oleh karena itu perlunya dilakukan penelitian ini untuk mengetahui kombinasi takaran pupuk kandang kambing dan pemberian pupuk uera yang dapat meningkatkan pertumbuhan dan hasil Pakcoy. Tujuan Penelitian untuk mengetahui Perlakuan pupuk Pupuk kadang kambing terhadap peningkatan luas daun, volume akar dan berat segar tanaman. Serta Interaksi pemberian pupuk Pupuk kadang kambing (t/ha) dan pupuk urea terhadap tanaman Pakcoy

\section{METODE PENELITIAN}

Penelitian ini dilakukan di Kampung Sona Kecamatan Rantau Sletan Kabupaten Labuhanbatu dengan ketinggian 18 meter diatas permukaan laut pada bulan Desember 2019 sampai bulan Maret 2020. Bahan yang digunakan adalah benih Pakcoy, pupuk kandang kambing. Pupuk uera, air Alat yang digunakan adalah pisau cutter,timbangan analitik, penggaris, gunting, mortar, labu ukur, ember, jangka sorong, tali rapiah, cangkul. Penelitian akan dilakukan dengan rancangan kelompok faktorial. Faktor pertama adalah pupuk kandang kambing $(\mathrm{K})$ yang terdiri dari 3 taraf: $\mathrm{K}_{1}=1 \mathrm{t} / \mathrm{ha}, \mathrm{K}_{2}=1,5$ $\mathrm{t} / \mathrm{ha}, \mathrm{K}_{3}=2 \mathrm{t} / \mathrm{ha}$ dan faktor kedua adalah Pemberian pupuk Urea (U) yang terdiri dari 2 taraf dosis : $U_{1}=75 \mathrm{~kg} / \mathrm{ha}, \mathrm{U}_{2}=100 \mathrm{~kg} / \mathrm{ha}$ , sehingga didapat 6 kombinasi perlakuan masing-masing 4 ulangan, sehingga diperoleh 24 plot. Setiap plot terdiri atas 25 tanaman dan diambil 5 tanaman sebagai sampel. Parameter yang diamati adalah tinggi tanaman $(\mathrm{cm})$, jumlah daun (helai), luas daun $\left(\mathrm{cm}^{2}\right)$, volume akar $(\mathrm{ml})$ dan berat berat segar tanaman (g). Data yang diperoleh dari hasil penelitian dianalisis secara statistik dengan sidik ragam dan Selanjutnya data dianalisis dengan ANOVA (Analisis Variansi pada setiap peubah amatan yang diukur dan diuji lanjutan bagi perlakuan yang nyata dengan menggunakan uji beda Duncan Multiple Range Test (DMRT) pada taraf 5\%.(Gomez dan Gomez, 1995).

\section{HASIL DAN PEMBAHASAN}

\section{Analisis Tanah Penelitian dan Kandungan Hara Pupuk Kandang Kambing}

Hasil analisis sampel tanah penelitian awal bahwa karakteristik tanah pada penelitian adalah memiliki kandungan $\mathrm{pH}$ $\left(\mathrm{H}_{2} \mathrm{O}\right) 5.32$ tergolong masam, kandungan $\mathrm{P}$ $\mathrm{P}_{2} \mathrm{O}_{5}$ Bray II (ppm) dan $\mathrm{K} \quad(\mathrm{mg} / 100 \mathrm{~g})$ masing-masing adalah 9,43 ppm dan 24,54 $\mathrm{mg} / 100 \mathrm{~g}$ tergolong sedang. Sedangkan serta C-Organik 1,84\% dan kandungan $\mathrm{N}$-total $0,27 \%$ tergolong rendah sehingga didapat nisbah C:N bernilai 6,81. Berdasarkan Kreteria Badan Penelitian dan Pengembangan Pertanian Kementerian Pertanian. 2012 bahwa tanah pada penelitian kandungan tergolong rendah dan sedang.

Adapun pupuk kandang kambing berdasarkan hasil analisis awal, pupuk kandang kambing yang digunakan memiliki kandungan $\mathrm{pH}\left(\mathrm{H}_{2} \mathrm{O}\right)$ 6,15, kandungan $\mathrm{P}$ (total) dan $\mathrm{K}$ (total), masing-masing adalah $1,7 \%$, dan $1,32 \%$. Berdasarkan nilai $\mathrm{pH}$ diketahui bahwa nilai $\mathrm{pH}$ yang dimiliki pupuk kandang kambing lebih tinggi bila dibandingkan dengan nilai $\mathrm{pH}$ tanah. Dengan demikian, pemberian pupuk kandang kambing diharapkan dapat meningkatkan nilai $\mathrm{pH}$ tanah dan berpengaruh terhadap perbaikan sifat fisik, kimia,dan biologinya Serta pertumbuhan dan Produksi Tanaman Sawi. Pupuk kandang kambing ini memiliki kandungan C-Organik $20,55 \%$ dan kandungan N-total $1,27 \%$ sehingga didapat nisbah $\mathrm{C}: \mathrm{N}$ bernilai 16,18 . Menurut Peraturan Menteri Pertanian (2009), pupuk organik siap untuk digunakan 
apabila nilai $\mathrm{C}$-organik $\geq 12$ dengan nisbah $\mathrm{C}: \mathrm{N}$ berkisar antara 15 sampai 25 .

\section{Tinggi Tanaman}

Rerata tinggi tanaman setelah dianalisis dengan sidik ragam menunjukkan bahwa interaksi perlakuan Pupuk kadang kambing (t/ha), perlakuan urea berpengaruh tidak nyata terhadap tinggi tanaman sawi. Hasil uji lanjut ditampilkan pada Tabel 1 .

Tabel 1. Rata-rata tinggi tanaman $(\mathrm{cm})$ dengan perlakuan beberapa dosis pupuk kandang kambing dan pupuk urea pada tanaman Pakcoy (Bressicca rapa $\mathrm{L}$ )

\begin{tabular}{cccc}
\hline \multirow{2}{*}{$\begin{array}{c}\text { Pupuk kandang kambing } \\
\text { (t/ha) }\end{array}$} & \multicolumn{2}{c}{ Pupuk Urea $(\mathrm{kg} / \mathrm{ha})$} & Rata-rata \\
\cline { 2 - 3 } & 75 & 100 & $28.74 \mathrm{a}$ \\
1,5 & $27,03 \mathrm{a}$ & $30.45 \mathrm{a}$ & $26.72 \mathrm{a}$ \\
2 & $32,86 \mathrm{a}$ & $20.59 \mathrm{a}$ & $31.52 \mathrm{a}$ \\
\hline Rata-rata & $34,61 \mathrm{a}$ & $28.44 \mathrm{a}$ & \\
\hline
\end{tabular}

Keterangan : Angka-angka pada baris dan kolom yang diikuti oleh huruf kecil yang sama berbeda tidak nyata menurut Uji DNMRT pada taraf 5\%.

Dari Tabel 1 menunjukkan bahwa pada pemberian perlakuan kombinasi pupuk Pupuk kadang kambing ( $\mathrm{t} / \mathrm{ha})$ dengan pupuk urea, pada tanaman sawi menunjukan berbeda tidak nyata pada tinggi tanaman. Pemberian perlakuan pupuk Pupuk kadang kambing (t/ha) pada dosis2 t/ha dan perlakuan pupuk urea $100 \mathrm{~kg} / \mathrm{ha}$ cenderung menunjukkan respon rerata tertinggi pada parameter pengamatan tinggi tanaman yaitu $34,61 \mathrm{~cm}$, dimana pada perlakuan tersebut tinggi tanaman sudah mencapai tinggi tanaman pada diskripsi tanaman Pakcoy (Bressicca Rapa L), hal ini dikarenakan kandungan unsur hara yang terdapat pada pupuk Pupuk kadang kambing ( $\mathrm{t} / \mathrm{ha}$ ) dan pupuk urea pada dosis ini sudah mampu memenuhi unsur hara pada tanaman dan mendukung pertumbuhan tinggi tanaman. Pertumbuhan tinggi pada tanaman sangat erat hubungannya dengan ketersediaan unsur hara makro salah satu diantaranya adalah Nitrogen $(\mathrm{N})$. Unsur $\mathrm{N}$ berperan dalam merangsang pertumbuhan vegetatif pada tanaman, salah satunya dalam peningkatan tinggi tanaman. Dalam hal ini dosis pupuk Pupuk kadang kambing (t/ha) $2 \mathrm{t} / \mathrm{ha}$ dan urea $100 \mathrm{~kg} / \mathrm{ha}$ sudah memadai sebagai penyedia unsur $\mathrm{N}$ yang secara langsung mempengaruhi ketersediaan hara $\mathrm{N}$ pada tanah, dan nitrogen yang berasal dari bahan oraganik pada Pupuk kadang kambing (t/ha) yang lebih tinggi lebih baik pengaruhnya karena Pupuk kadang kambing (t/ha) menjadi unsur hara yang lebih lengkap, dan pupuk ini mengandung C-Organik (20,55\%),N-total (1,27\%)sedangkan C:N bernilai $(16,18), \quad \mathrm{K}_{2} \mathrm{O} \quad(4,47 \%)$, $\mathrm{P}_{2} \mathrm{O} 5(3,24 \%)$ Kadar air $(12,15 \%)$ (Syamsuddin dan Faesal, 2003). Pemberian $\mathrm{N}$ dari urea pada dosis rendah, kebutuhan $\mathrm{N}$ untuk tanaman telah terlengkapi dan tidak terjadi kekurangan N. Menurut Nyakpa et al., (1988) bahwa kekurangan $\mathrm{N}$ akan membatasi produksi protein dan bahan penting lainnya dalam pembentukan sel baru pada tanaman.

\section{Jumlah Daun}

Rerata jumlah daun setelah dianalisis dengan sidik ragam menunjukkan bahwa interaksi perlakuan Pupuk kadang kambing (t/ha) dan perlakuan urea berpengaruh tidak nyata terhadap jumlah daun tanaman Pakcoy (Bressicca Rapa L). Hasil uji lanjut ditampilkan pada Tabel 2. 
Tabel 2.Rata-rata Jumlah daun dengan perlakuan beberapa dosis pupuk kandang kambing dan pupuk urea pada tanaman Pakcoy (Bressicca rapa $\mathrm{L}$ )

\begin{tabular}{cccc}
\hline \multirow{2}{*}{$\begin{array}{c}\text { Pupuk kandang } \\
\text { kambing (t/ha) }\end{array}$} & 75 & 100 & Rata-rata \\
\cline { 2 - 3 } & & $8,08 \mathrm{a}$ & \\
\hline 1 & $8,25 \mathrm{a}$ & $7,46 \mathrm{a}$ & $8,17 \mathrm{a}$ \\
2 & $7,92 \mathrm{a}$ & $8,58 \mathrm{a}$ & $7,69 \mathrm{a}$ \\
\hline Rata-rata & $9,17 \mathrm{a}$ & $8,04 \mathrm{a}$ & \\
\hline
\end{tabular}

Keterangan : Angka-angka pada baris dan kolomyang diikuti oleh huruf kecil yang sama berbeda tidak nyata menurut uji DNMRT pada taraf $5 \%$

Dari Tabel 2 menunjukkan bahwa pada pemberian perlakuan kombinasi pupuk Pupuk kadang kambing ( $\mathrm{t} / \mathrm{ha}$ ) dengan pupuk urea pada tanaman sawi menunjukan berbeda tidak nyata pada jumlah daun. Pemberian perlakuan pupuk Pupuk kadang kambing (t/ha) pada dosis 2 t/ha dengan pupuk urea $100 \mathrm{~kg} / \mathrm{ha}$ cenderung menunjukkan respon rerata jumlah daun tertinggi yaitu 9,17 helai.Semua perlakuan menunjukkan belum optimalnya jumlah daun karena pertumbuhan jumlah daun selain dipengaruhi pasokan hara dari pupuk juga dipengaruhi oleh hara yang tersedia pada tanah. Kondisi ini disebabkan karena pembentukan sel-sel baru dalam suatu tanaman ditentukan oleh ketersediaan hara pada tanah. Proses pembentukan daun tidak terlepas dari peranan unsur hara seperti nitrogen dan fosfat yang terdapat pada medium tanah dan dalam kondisi tersedia bagi tanaman (Nyakpak et al., 1988). Secara umum apabila tanaman kekurangan unsur hara tersebut akan mengganggu kegiatan metabolisme tanaman sehingga proses pembentukan daun yang dalam hal ini selsel baru akan terhambat.

Ketersediaan nitrogen yang rendah menyebabkan aktifitas sel-sel yang berperan dalam kegiatan fotosintesis tidak dapat memanfaatkan energi matahari secara optimal sehingga laju fotosintesis akan menurun dan fotosintat yang dihasilkan lebih sedikit. Kondisi ini akan memperlambat laju pertumbuhan dan perkembangan tanaman khususnya dalam pembentukan organ baru.Hal ini disebabkan oleh tidak terpenuhinya kebutuhan unsur hara terutama $\mathrm{N}$ yang berperan dalam pertumbuhan vegetatif tanaman.

\section{Luas Daun}

Rerata luas daun setelah dianalisis dengan sidik ragam menunjukkan bahwa interaksi perlakuan Pupuk kadang kambing (t/ha) dan perlakuan urea berpengaruh nyata terhadap luas daun tanaman sawi. Hasil uji lanjut ditampilkan pada Tabel 3

Tabel 3.Rata-rata luas daun terlebar dengan perlakuan perlakuan beberapa dosis pupuk kandang kambing dan pupuk urea pada tanaman Pakcoy (Bressicca rapa $\mathrm{L}$ )

\begin{tabular}{cccc}
\hline $\begin{array}{c}\text { Pupuk kandang } \\
\text { kambing (t/ha) }\end{array}$ & 75 & 100 & Rata-rata \\
\cline { 2 - 3 } 1 & $195.20 \mathrm{a}$ & $196.20 \mathrm{a}$ & \\
\hline 1,5 & $198.24 \mathrm{a}$ & $197.25 \mathrm{a}$ & $195.7 \mathrm{a}$ \\
2 & $202,93 \mathrm{a}$ & $201,93 \mathrm{a}$ & $197.7 \mathrm{a}$ \\
\hline Rata-rata & $198,77 \mathrm{a}$ & $198.78 \mathrm{a}$ & \\
\hline
\end{tabular}

Keterangan : Angka-angka pada baris dan kolomyang diikuti oleh huruf kecil yang sama berbeda tidak nyata menurut uji DNMRT pada taraf $5 \%$. 
Dari Tabel 3 menunjukkan bahwa pada pemberian perlakuan kombinasi pupuk Pupuk kadang kambing ( $\mathrm{t} / \mathrm{ha}$ ) dengan pupuk urea pada tanaman sawi menunjukan berbeda nyata pada luas daun. Pemberian perlakuan pupuk Pupuk kadang kambing (t/ha) pada dosis $2 \mathrm{t} / \mathrm{ha}$ dan pupuk urea100 $\mathrm{kg} / \mathrm{ha}$ menunjukkan respon rerata luas daun terluas yaitu 202,93 $\mathrm{cm}^{2}$ dan diikuti dengan Pupuk kadang kambing (t/ha) pada dosis 2 t/ha dan pupuk urea $100 \mathrm{~kg} / \mathrm{ha}$ rerata luas daun terluas yaitu $19520 \mathrm{~cm}^{2}$. Parameter luas daun dapat menggambarkan kualitas dari sayuran.Semakin besar luas daun maka semakin berkualitas suatu tanaman dan semakin tinggi nilai jualnya. Menurut Kelik (2010), parameter luas daun ini dapat memberi gambaran tentang proses dan laju fotosintesis pada suatu tanaman, dengan luas daun yang tinggi, maka cahaya akan lebih mudah diterima oleh daun dengan baik. Cahaya merupakan sumber energi yang digunakan untuk melakukan pembentukan fotosintat yang pada akhirnya berkaitan dengan pembentukan biomassa tanaman. Selanjutnya Plaster (2003), mengatakan bahwa nitrogen lebih diperlukan dalam menunjang pertumbuhan bagian vegetatif dibandingkan generatif dan penting bagi tanaman sayuran yang dikonsumsi bagiantajuknya, pemberian nitrogen dalam jumlah yang cukup, menghasilkan tanaman yang vigor dan ukuran daun yang besar.

Faktor yang berpengaruh terhadap luas daun pada suatu tanaman adalah nitogen, fosfor dan kalium. Salah satu fungsi fosfor adalah untuk perkembangan jaringan meristem (Sarief, 1985). Jaringan meristem terdiri dari meristem pipih dan meristem pita. Meristem pita akan menghasilkan deret sel yang berfungsi dalam memperpanjang jaringan sehingga daun tanaman akan semakin panjang dan lebar, serta akan mepengaruhi luas daun tersebut (Heddy,1987).

\section{Volume Akar}

Rerata volume akar setelah dianalisis dengan sidik ragam menunjukkan bahwa interaksi perlakuan Pupuk kadang kambing (t/ha) dan perlakuan urea berpengaruh tidak nyata terhadap volume akar tanaman sawi. Hasil uji lanjut ditampilkan pada Tabel 4

Tabel 4. Rata-rata volume akar dengan perlakuan perlakuan beberapa dosis pupuk kandang kambing dan pupuk urea pada tanaman Pakcoy (Bressicca rapa L)

\begin{tabular}{cccc}
\hline $\begin{array}{c}\text { Pupuk kandang } \\
\text { kambing (t/ha) }\end{array}$ & 75 & 100 & Rata-rata \\
\cline { 2 - 3 } & & & \\
\hline 1 & $4,36 \mathrm{a}$ & $4,38 \mathrm{a}$ & $4,37 \mathrm{a}$ \\
2 & $4,66 \mathrm{a}$ & $4,66 \mathrm{a}$ & $4,66 \mathrm{a}$ \\
\hline Rata-rata & $5,56 \mathrm{a}$ & $5,56 \mathrm{a}$ & $5,56 \mathrm{a}$ \\
\hline
\end{tabular}

Keterangan : Angka-angka pada baris dan kolomyang diikuti oleh huruf kecil yang sama berbeda tidak nyata menurut uji DNMRT pada taraf $5 \%$.

Dari Tabel 4 menunjukkan bahwa pada pemberianperlakuan kombinasi pupuk Pupuk kadang kambing ( $\mathrm{t} / \mathrm{ha}$ ) dengan pupuk urea pada tanaman sawi menunjukan berbeda tidak nyata pada volume akar. Pemberian perlakuan pupuk Pupuk kadang kambing ( $\mathrm{t} / \mathrm{ha}$ ) pada dosis $2 \mathrm{t} / \mathrm{ha}$ dan pupuk urea $100 \mathrm{~kg} / \mathrm{ha}$ cenderung menunjukkan respon rerata tertinggi pada parameter pengamatan volume akar yaitu $5,56 \mathrm{ml}$. Hal ini disebabkan karena pemberian pupukPupuk kadang kambing ( $\mathrm{t} / \mathrm{ha}$ ) dapat meningkatkan kandungan unsur hara di dalam tanah sehingga dapat meningkatkan volume akar tanaman. Selain itu menurut Gardner et al., (1991), pertumbuhan suatu 
tanaman diikuti dengan pertumbuhan bagian tanaman lainnya, dimana tajuk akan meningkat dengan mengikuti peningkatan berat akar.

Pemberian pupuk Pupuk kadang kambing ( $\mathrm{t} / \mathrm{ha}$ ) dosis $2 \mathrm{t} / \mathrm{ha}$ memiliki volume akar yang terbesar,karena dengan meningkatan dosis pupuk Pupuk kadang kambing (t/ha) dan pupuk ureaketersediaan unsur hara bagi tanaman akan meningkat sehingga volume akar tanaman menjadi lebih besar untuk menyerap unsur hara. Menurut Yuwono (2007), salah satu fungsi pupuk organik adalah memperbaiki struktur tanah. Tanah yang baik adalah tanah yang mempunyai tata udara yang baik sehingga aliran udara dan air dapat masuk dengan baik sehingga perakaran tanaman akan berkembang lebih baik, semakin banyak pupuk organik yang diberikan maka akan semakin baik aerase dan drainase tanah dan akan semakin baik pula pertumbuhan akar tanaman.

\section{Berat Segar pertanaman}

Rerata berat segar tanaman setelah dianalisis dengan sidik ragam menunjukkan bahwa interaksi perlakuan Pupuk kadang kambing (t/ha) dan perlakuan urea berpengaruh nyata terhadap berat segar tanaman pada tanaman sawi. Hasil uji lanjut ditampilkan pada Tabel 5.

Tabel 5. Rata-rata berat segar tanam dengan perlakuan beberapa dosis pupuk kandang kambing dan pupuk urea pada tanaman Pakcoy (Bressicca rapa $\mathrm{L})$

\begin{tabular}{cccc}
\hline $\begin{array}{c}\text { Pupuk kandang } \\
\text { kambing (t/ha) }\end{array}$ & 75 & 100 & Rata-rata \\
\cline { 2 - 3 } & $11,48 \mathrm{a}$ & $26,00 \mathrm{a}$ & \\
\hline 1,5 & $10,68 \mathrm{a}$ & $38,00 \mathrm{a}$ & $18,74 \mathrm{a}$ \\
2 & $11,88 \mathrm{a}$ & $40,00 \mathrm{a}$ & $24,34 \mathrm{a}$ \\
\hline Rata-rata & $8,44 \mathrm{a}$ & $8,04 \mathrm{a}$ & $25.94 \mathrm{a}$ \\
\hline
\end{tabular}

Keterangan : Angka-angka pada baris dan kolomyang diikuti oleh huruf kecil yang sama berbeda tidak nyata menurut uji DNMRT pada taraf $5 \%$.

Dari Tabel 5 menunjukkan bahwa pada pemberian perlakuan kombinasi pupuk pupuk kadang kambing ( $\mathrm{t} / \mathrm{ha}$ ) dengan pupuk urea pada tanaman sawi menunjukan berbeda nyata pada berat segar tanaman. pemberian perlakuan pupuk pupuk kadang kambing ( $\mathrm{t} / \mathrm{ha})$ pada dosis $2 \mathrm{t} / \mathrm{ha}$ dan pupuk urea $100 \mathrm{~kg} / \mathrm{ha}$ menunjukkan respon rerata tertinggi pada parameter pengamatan berat segar tanaman yaitu 40,00g, respon terendah terdapat pada tarafperlakuan interaksi pupuk pupuk kadang kambing (t/ha) 1 t/ha dan pupuk urea $75 \mathrm{~kg} / \mathrm{ha}$ yaitu $11,88 \mathrm{~g}$. hal ini karena semakin meningkat dosis yang diberikan mampu menyediakan unsur hara dalam jumlah yang cukup untuk pertumbuhan dan produksi sawi sehingga kegiatan metabolisme dan akumulasi asimilat pada daerah daun dan batang tanaman meningkat dan mempengaruhi berat segar tanaman tersebut.berat segar tanaman mencerminkan komposisi hara pada pupuk pupuk kadang kambing (t/ha) dapat dijadikan pupuk lengkap karena didalamnya terkandung zat nitrogen .kandungan nitrogen berfungsi merangsang pertumbuhan tanaman sawi sehingga bahan organik yang disuplay dari pupuk kadang kambing (t/ha) dapat meningkatkan unsur hara pada tanah, termasuk unsur hara makro yaitu salah satunya nitrogen menurut Cahyono $\mathrm{B}$. (2003) Pemberian pupuk kadang kambing (t/ha) dan pupuk urea berpengaruh terhadap pertumbuhan tanaman sawi karena mengandung unsur hara dalam jumlah cukup yang sangat diperlukan pertumbuhan tanaman sawi. 


\section{KESIMPULAN}

1. Perlakuan pupuk Pupuk kadang kambing ( $\mathrm{t} / \mathrm{ha}$ ) dengan dosis $2 \mathrm{t} / \mathrm{ha}$ dan pupuk urea dosis $100 \mathrm{~kg} / \mathrm{ha}$ mampu menghasilkan peningkatan luas daun, volume akar dan berat segar tanaman.

2. Interaksi pemberian pupuk Pupuk kadang kambing ( $\mathrm{t} / \mathrm{ha})$ dan pupuk urea memberikan pengaruh yang nyata pada parameter luas daun, volume akar dan berat segar tanaman.

\section{DAFTAR PUSTAKA}

Badan Penelitian dan Pengembangan Pertanian Kementerian Pertanian. 2012.Petunjuk Teknis Analisis Kimia Tanah, Tanaman, Air dan Pupuk. Edisi2. Bogor. 204 hal

Fadhillah, W. and Harahap, F.S., 2020. Pengaruh Pemberian Solid (Tandan Kosong Kelapa Sawit) Dan Arang Sekam Padi Terhadap Produksi Tanaman Tomat. Jurnal Tanah dan Sumberdaya Lahan, 7(2), pp.299304.

Gomez, K.A. and Gomez, A.A., 1995. Prosedur statistik untuk penelitian pertanian Edisi Kedua. Sjamsuddin E, Baharsjah JS, penerjemah. Jakarta (ID): UI pr. Terjemahan dari: Statistical Procedures for Agricultural Research.

Harahap, F.S. and Fitra, Y.R., 2020. Characteristics of Chemical Properties of Oil Palm Soil at Plant Age in Different Areas of Land. Jurnal Pertanian Tropik, 7(2, Agustus), pp.233-238.

Harahap, F.S. and Sari, P.M., 2019. Growth and production response of plant pakcoy (brassica rapa 1) on use of nasa light organic fertilizer. Jurnal Pertanian Tropik, 6(2), pp.222-226.

Harahap, F.S., Rauf, A., Rahmawaty, R. and Sidabukke, S.H., 2018. Evaluasi kesesuaian lahan pada areal penggunaan lain di Kecamatan Sitellu Tali Urang Julu Kabupaten Pakpak Bharat untuk pengembangan tanaman cabai merah (Capsicum annuum L.). Jurnal Tanah dan Sumberdaya Lahan, 5(2), pp.829839.

Harahap, F.S., Roswita, O. and Iman, A., 2020. Supply Liquid Organic Fertilizer NASA and Rice Husk Ash To The Chemical Properties Of The Soil On The Tomato Plant. International Journal of Science, Technology \& Management, 1(3), pp.185-189.

Harahap, F.S., Walida, H., Oesman, R., Rahmaniah, R., Arman, I., Wicaksono, M., Harahap, D.A. and Hasibuan, R., 2020. Pengaruh Pemberian Abu Sekam Padi Dan Kompos Jerami Padi Terhadap Sifat Kimia Tanah Ultisol Pada Tanaman Jagung Manis. Jurnal Tanah dan Sumberdaya Lahan, 7(2), pp.315320.

Harahap, F.S., Walida, H., Rahmaniah, R., Rauf, A., Hasibuan, R. and Nasution, A.P., 2020. Pengaruh Aplikasi Tandan Kosong Kelapa Sawit dan Arang Sekam Padi terhadap beberapa Sifat Kimia Tanah pada Tomat. Agrotechnology Research Journal, 4(1), pp.1-5.

Harahap, F.S.H., Walida, H., Harahap, D.A., Oesman, R. and Fadhillah, W., 2019. Response of Growth and Production 
of Corn (Zea Mays L) with Liquid Fertilizer in Labuhan Batu Regency. Jurnal Pertanian Tropik, 6(3), pp.363-370.

Hartatik, W., D. Setyorini, L. R. Widowati dan S. Widati. 2005. Laporan Akhir PenelitinTeknologi Pengelolaan Hara Pada Budidaya Pertanian Organik. Laporan Bagian Proyek Penelitian SumberdayaTanah dan Proyek Pengkajian Teknologi Pertanian Persentatif.

Hayati, E., Sabarudin., dan Rahmawati. 2012. Pengaruh jumlah mata tunas dan komposisi media tanam terhadap pertumbuhan setek tanaman jarak pagar (Jatropha curcas L.). Agrivista. 3:129-134.

Heddy, S. 1987. Hormon Tumbuhan. PT. Rajawali. Jakarta.

Irwan. 2005. Pengaruh Dosis Karci dan Pupuk kadang kambing (t/ha) Terhadap Pertumbuhan dan Hasil Tanaman Sawi (Brassica rapaL.) Yang Dibudidayakan secara Organik.

Nyakpa, M. Y, A, M. Lubis. M, A. Pulung, Amrah, A. Munawar, G, B. Hong, N. Hakim. 1988. Kesuburan Tanah. Universitas Lampung Press.

Peraturan Menteri Pertanian No. 70/Permentan/SR.140/10/201 1. Pupuk Organik, Pupuk Hayati, dan Pembenah Tanah - PP No.18 Tahun 1999 tentang Pengelolaan Limbah B3.

Rahmawaty, R., Frastika, S., Rauf, A., Batubara, R. And Harahap, F.S., 2020. Land suitability assessment for Lansium domesticum cultivation on agroforestry land using matching method and geographic information system. Biodiversitas Journal of Biological Diversity, 21(8).
Statistik, B.P., 2016. Data Susenas 2016. Jakarta (ID): Badan Pusat Statistik Indonesia

Surya, E., Hanum, H., Hanum, C., Rauf, A., Hidayat, B. and Harahap, F.S., 2019. Effects of Composting on Growth and Uptake of Plant Nutrients and Soil Chemical Properties After Composting with Various Comparison of POME. International Journal of Environment, Agriculture and Biotechnology, 5(6).

Syekhfani. 2000. Pertanian organik: suatu alternatif menuju sistem pertanian berkelanjutan (ditinjau dari aspek kesuburan tanah). Dinas Pertanian Tanaman Pangan, Jawa Timur.

Syukur, A., 2006. Kajian pengaruh pemberian macam pupuk organik terhadap pertumbuhan dan hasil tanaman jahe di Inceptisol, Karanganyar. Jurnal Ilmu Tanah dan Lingkungan, 6(2006).

Tan, K. H. 1993. Environmental soil science. Marcel Dekker. Inc, New York.

Walida, H., Harahap, F.S., Dalimunthe, B.A., Hasibuan, R., Nasution, A.P. and Sidabukke, S.H., 2020. Pengaruh Pemberian Pupuk Urea Dan Pupuk Kandang Kambing Terhadap Beberapa Sifat Kimia Tanah Dan Hasil Tanaman Sawi Hijau. Jurnal Tanah dan Sumberdaya Lahan, 7(2), pp.283-28.

Walida, H., Harahap, F.S., Hasibuan, M. and Yanti, F.F., 2019. Isolasi dan Identifikasi Bakteri Penghasil IAA dan Pelarut Fosfat dari Rhizosfer Tanaman Kelapa Sawit. BIOLINK (Jurnal Biologi Lingkungan Industri Kesehatan), 6(1), pp.1-7. 
Wijaya, K., 2010. Pengaruh konsentrasi dan

pertumbuhan tanaman sawi frekuensi pemberian pupuk organik

(Brassica rapa 1.). cair hasil perombakan anaerob limbah makanan terhadap 